\title{
Development of Counter-Narrative Delivery Strategies by Former Terrorist as Disengagement Effort In Indonesia
}

\author{
Nanda Fajar Aditya ${ }^{1}$, Muhammad Luthfi ${ }^{2}$, Muhammad Imdadun Rahmat ${ }^{3}$, \\ Mulawarman Hannase ${ }^{4}$ \\ $\left\{{ }^{1}\right.$ nanda.fajar.indonesia@gmail.com, ${ }^{2}$ m.luthfiz009@gmail.com, ${ }^{3}$ imdadunrahmat@yahoo.com, \\ ${ }^{4}$ mulawarmanhannase@ui.ac.id\} \\ ${ }^{1,2,3,4}$ School of Strategic and Global Studies, Universitas Indonesia, Indonesia
}

\begin{abstract}
Disengagement has a strategic role as an effort to change the radicalism level for terrorist actors who have been exposed to radical thinking so they willing to leave the violence group. To reduce the radicalism level, effective counter-narrative delivery strategies is needed to influence the terrorist offender's mindset. One of the narrators that could be considered is former terrorists. Former terrorists give a positive influence in accordance with their experience in undermining the narrative carried by the radical groups. The offenders will assume that the ideology they believe is no longer relevant. This study is expected to contribute to the development of counter-narrative delivery strategies trough former terrorist involvement so that disengagement effort can be maximized. In this study, the author will use a qualitative method to understand a phenomenon in more personal and detail way. The result of this study observes with the right engagement strategy, the former terrorist can be an effective agent to change the perception through the mastery of the narrative it possesses. The former terrorist cannot be considered an outsider in the disengagement program, but they need to be more actively involved because they could act as credible narrator.
\end{abstract}

Keywords: Disengagement, Former Terrorist, Counter-Narrative

\section{INTRODUCTION}

The development of counter-narrative strategy is needed as an effort to reduce radicalism level of offenders who have been exposed to radical thinking. To reduce radicalism level requires an effective narrative strategy to influence the offenders to lower the radical ideology level they believe and to leave the violence group. The effort is not possible through hardapproach because ideology is the power of the offenders to believe that their actions as truth (Hassan in Horgan \& Braddock, 2012). Although there are various attempts at acting to the terrorist organization leader, their fight will survive because the organization ideology will continuously exist on its followers' ideology (Hassan in Horgan \& Braddock, 2012). Softapproaches are needed because ideologies are likened to a spring. The more it is pressed by means of violence, the more the offenders will repay in violence way (Hanif, 2018). To 
respond to that, so soft-approach is needed through a counter-narrative strategy to counter extremist ideas so that the offenders is willing to leave the violent group.

One of the most effective counter-narrative narrators is a former terrorist (Jacobson, 2010; Rabasa, et.al, 2010). The former terrorists (former) have the advantage of being able to give influence in accordance with their experience to purposely undermining the narrative carried by the radical group so the message receiver will assume that his ideology is no longer relevant (Jacobson, 2009). The formers also able to become a mediator against the radical group's demands that needed to be accommodated through the national government because terrorism networks operate in secret. The roles of muftis or religious leaders sometimes have various obstacles so that the former could be empowered to bring terrorist extremist to repentance (Idris \& Taufiqurrahman, 2015; Rabasa, et.al, 2010).

The coaching efforts by the state government is not maximum due to the offender's assumption that the state coaching agents area representation of thaghut (demon) so the role of the formers have a vital role as the peace messenger (Ibrahim 2018). The state and even civil society agent will be regarded as an outsider causing the offenders resistant to the counternarratives delivered (Ibrahim 2018). Meanwhile, Glazzard (2017) stated that the counternarrative conveyance of the state and civil society was done without sufficient theoretical base on the target audience and was likely to be presented based on a series of assumptions. The study by Hemmingsen and Castri (2017) also explained that the counter-narrative efforts is being done without sufficient knowledge of the target audience because they have not yet understood the radicalization process experienced by the terrorist itself. To convey effective counter-narrative in order to moderate ideology, it is necessary to have a deep comprehend by understanding the personal characteristic of the offenders (Al-Raffie, 2012). The problems mentioned above need to be solved by academic solutions so that acceptance of counternarratives by the offenders is effective to reduce their radical understanding. The researcher sees the need for credible involvement of messenger, especially from their own inner circle who understands their background, characteristic and individual causative factors that makes someone believe in an extreme ideology that leads to terrorism.

The researcher uses the disengagement concept rather than deradicalization because researcher saw that disengagement efforts are more realistic and can be seen from the offenders behavior. Disengagement is a process where each member of a terror group or radical movement choose to not participate in violent action (Hwang, 2017). They decided to abandon the movement or replace its role from the violence way to non-violence (Hwang, 2017).

There is a change of role from the previous violent-radical to radical in term of thinking (Horgan \& Braddock, 2010). On the other hand, one may still show some obedience to longstanding values and behavioral attitudes but are no longer involved in actual terrorism operations (Horgan, 2008). From the explanation above, it can be concluded that one might has left a commitment to violence already, but they still have a radical understanding.

This research is important to fill the gap of research against the counter-narrative delivery strategy from the formers' point of view so that disengagement efforts run optimally in Indonesia. A research theme of formers involvement as counter-narrative deliver agent targeting to circle who had been exposed to radicalism have never been published in an international and national journal before. However, there are some writings study about the formers role in some areas in European such as formers role of Irish Republican Army/ IRA in North Ireland (Clubb, 2016), Formers role of Neo-Nazi Group in Germany (Christensen, 2015), formers role of Euskadi Ta Askatasuna/ETA group in Basque-Spanyol (Alonso, 2016). In addition, there is a wider discussion on the involvement of the formers and the victims in 
Europe (Argomaniz\&Lynch, 2017) and United State of America (Jacobson, 2009). The study of formers involvement in Indonesia has unique network, culture and approaches so it is strategic enough to be examined thoroughly.

In conducting data mining, the researcher conducted interview with 14 (Fourteen) former based on various background cases: 3 (three) people were involved in the ISIS network, 3 (three) people were involved in military training case (i'dad) in Jalin Janto mountains in Aceh, 1 (one) person were involved in Cibiru Bomb in Bandung, 2 (two) people were involved in first Bali Bomb, 1 (one) formers was involved in JI network and Philippine conflict, 2 (two) people were involved in Ambon conflict and arms supply to the terrorist group, 2 (two) people were involved in the CIMB Niaga robbery (fa'i). Researcher also observed their interaction to the other on their daily activities and conducting literacy study of various books, national and international journals.

This research is expected to contribute to the development of counter-narrative strategy development through the formers involvement so that the disengagement effort can be run maximally. The researcher has hypotheses trough appropriate engagement strategies, the formers can be an effective change agent to alter the terrorist behavior trough mastering the counter-narrative they have. The formers cannot be considered as outsiders in the engagement program, but instead, they should actively be involved.

\section{COUNTER-NARRATIVE}

According to Scott Ruston (2009), basically narrative is a link system of the story to explain the coherent views of the world through the incorporation of data and the patterns (how to communicate and what does not to convey). Here it appears that the narrative is not just related to the message, but it is related to the appropriate delivery strategy.

Counter-narrative has several different spectra, they are counter-narrative and alternative narrative. The main goal of counter-narrative is to fight irrational extreme narrative and also to influence extremists psycho-emotional (Schmid, 2014). Briggs\& Feve (2013) specifically explains that counter-narrative itself can be defined as a deconstruction effort, discredit and obscure the extreme and violent messages myths that lead to violence (Briggs \&Feve. 2013). It may also mean an attempt to combat extreme and violent message directly or indirectly through online or offline by resisting the ideology, logic, and facts (Briggs \&Feve. 2013); second, The Alternative Narrative. Alternative Narrative does not contradict radical thinking with direct confrontation as done by counter-narratives but gives a positive story of social value, tolerate, openness, freedom, and democracy (Briggs \& Feve, 2013). The alternative narrative does focus on who we are and what we are meant to be rather than what we are opposed, besides that alternative narrative are also rooted in the culture and traditions owned (Schmid, 2016). It can be concluded that alternative narrative is more subtle than counternarrative.

Based on the result of the interview, the formers presented 2 (two) main things which became the legitimation for their involvement in the violent act, they are the understanding of Takfir and Jihad. Takfir is addressing to people outside his group whether it is a different religious faith or people who do not practice Islam according to their way. They are who were not in their group, or do not like-minded with their faith, and who are not at odds with the caliphate in Syria are refer to the infidel (Patek, 2018). As a consequence of the interpretation, it is allowed to be killed and taken away their property (Patek, 2018). The formers explained that the understanding of takfir becomes a fundamental basis for being bound in the group to fight the thaghut (demon). Even when a person who has pledge (baiat) does not claim other 
people outside their group as infidel so that person also claimed as infidel also (Tsauri, 2018). Someone who does not condemn the law of Allah is an infidel, including their own parents (Hasan, 2018). The understanding of takfir or infidelity also influencing people to have extreme behaviors including refusing food or involved in a fight with their own parents (Hasan, 2018). Khairi (2018) also added, Islam for takfir believer is fighting the thaghut.

Next is the obligation to implement jihad. Jihad is an obligation to achieve the goal of enforcing daulah-Islamiyah with Islamic law within. It was revealed by a former who was once joined to jihadist in Ambon. They stated if there is one Muslim area that attacked by the infidels, its obligatory for them to defend the Muslim (Hasan, 2018). It was agreed by Ibrahim (2018) who assumed that at that time the nation was deemed to fall into defending the Islamic community so that the non-formal movements were needed to defend the Muslim in various conflict areas. A dilemmatic view was raised by a former who had been involved in military training in Aceh. He said he was forced to break the positive law for religious interest. God orders to go for jihad or there will be a punishment in the Hereafter. But on the other hand, the government prohibited jihad or the one who violate the law will be subject to prison (Khairi,2018).

\section{COUNTER-NARRATIVE AS DISENGAGEMENT EFFORT}

There is no standard of solid counter-narrative delivery strategies in conducting the disengagement so the counter-narrative need to adapt to the type of audience they want to be invited to. There is an assumption that the disengagement full of religious narrative. This assumption is true, but if not matched with humanity messages, the disengagement effort will meet the obstacle.

Religious Narrative, related to religious narrative, the formers try to explain that there was a misunderstanding of the violent narrative that they believe. In other words, religious narrative presented attempts to dissect the wrong logic structure or path so that it can be disadvantaged by the narrative they believe. The coaching for offenders requires a theological dialogue so they can be assured that their interpretation related to the violence understanding are wrong (Rabasa, et.al., 2010). On religious narrative, the formers and the offenders discussed the context of interpretation and jihad's meaning as the main ideological instrument. In addition, the formers may discuss other additional arguments, such as al-wala wal-baro meaning (to do good to others and to oppose the opponent), baiat (loyal oath to the leader), fa'i (robbery for the sake of jihad), istisyhad (sacrifice life), darul al-harb (war territory), hijrah (moving from bad territory to goodness) and ghuroba (alienation). All of them above needs to be understood by the entire formers involved in disengagements, thus balancing the narrative of violence that the perpetrator understands. For example, Khairi (2018) in his disengagement process considered the most important argument to be submitted to moderate himself was related to Udzur bil Jahl. Udzur bil Jahl is legal tolerance according to specific condition. Someone needs to compare which scholar give tolerance and what kind of condition the law can be applied (Khairi, 2018).

Humanitarian narrative. Humanitarian narratives are more touching the psychological side of the perpetrator. The humanitarian narrative is required because the offenders are those who are not easily thought in term of ideology. They will create a distance if someone threatened their faith (Sageman, 2008). They argue that counter-narrative efforts through religious discourse are the same as de-ideologization. They could be bored and refuse to hear the couch (Sageman, 2008). There is a fort that must be emerging gradualy so that the perpetrators want to lower their radicalism level. There is no instant solution to degrade the ideological beliefs. 
Based on the interview with Abu Azzam (2017), a formers that involved in Fa'i CIMB Niaga stated that:

"not all terrorist can be approached with a religious proposition. Even I myself

feel just as a "warrior" with limited religious knowledge. But I understand that the most important thing for Moslem is good morals and jihad by supporting my family and children."

The offenders need to be touched by their humanitarian side especially with regards to family, education, economic and even security threats from their previous radical network. The humanitarian approach should not be of expensive, but the most important is the consistent attention to listening to the problems experienced by the offenders. They need to be given an alternative to jihad activities that force them to deal with law enforcement officer. In addition, the narrative of humanity can touch on the aspect of economic independence so that offenders has a decent living source and do not think back to commit to violence. With the formers' involvement that touches their humanity side, it is expected that the offenders who still radical may evaluate that the terror group morality is incompatible with the real situation and their movement is not relevant (Hanif, 2018). That humanitarian narrative is well applied to the Lingkar Perdamaian Foundation managed by Ali Fauzi, a formers from Lamongan who has been involved in Jamaah Islamiyah network and as a Philippine Jihadist. The foundation established in 2017, serves as a platform for the formers and their family to become independent and have a normal life in the society. Ali Fauzi and his colleagues not only uses religious narratives as a major narrative but rather a humanitarian approach. For example, he gives the job to newly formers released prisoners or being a mediator between the government and the formers who need health and education assistance. This support was done not only to those who were affiliated to the Jamaah Islamiyah, but some former ISIS supporters also take a role in the foundation Ali Fauzi shelter. For example, there is an ex- Poso conflict case whose parents also affiliated with Islamic State (IS). The former gets access to work through the foundation network at a store to be able to live independently and start a new life.

\section{FORMER TERRORIST STRATEGY IN DISENGAGEMENT EFFORT}

The former terrorist in this research is defined as someone who once had extreme ideas or had extreme behavior (Sieckelinck \& Winter, 2015). The formers is those who undergone a deradicalization process and/or undergone a disengagement process (Sieckelinck \& Winter, 2015). The formers has had a change of view and plural behavior, tolerant and peaceful. The former has the advantage and credibility since they havea social relationship with someone who has hatred and involved in the violent movement (Braddock \& Horgan 2015) so they are regarded as a competent person to have a dialogue about the ideology they believe (Benford \& Snow, 2000). This was revealed by Kurnia Widodo (2018), a former of Cibiru Bomb who got disengage from Jamaah Islamiyah figures. He said that: "Those former jihadists make an impact on me because they are not only babbling around but they really give an influence on me". The formers involvement is a logical verdict because without sufficient knowledge of the different views, counter-ideological efforts will be ineffective and alternative ideas will not be well communicated even can cause the offenders to be even more radical. (Hassan in Horgan \& Braddock, 2012).

The formers take a role in 3 (three) important areas. First, they take a role as medium or mediator, they do not conduct ideological moderation directly, but through a humanitarian approach as a friend to discuss, provide economic assistance, shelter and employment; second, 
they are the messenger to the government and stakeholder. They provide assurance that following government-sponsored activities or civil society to gain some benefit; third, the formers play a role in moderating ideology. The formers in this category has the adequate religious knowledge and is likely to be established within the network. In delivering counternarrative effectively, the formers can combine these three areas.

The formers is able to identify radical network better than government or civil society because they have psychological closeness and are able to use easy-to-understand everyday language, thus reducing suspicion to targets that they will be arrested again. According to Ibrahim (2018), the psychological proximity and gaining trust is formed over the years. He said that network activist provides material and moral assistance to each other so that they are bonded internally. They live together in the prisons, sharing food together, exercising together, praying together, providing economic assistance or just giving up the spirit when they got the problem. Even when they are free from the prison, they continue to establish a relationship. AA (initial) a former terrorist of IS network emphasized that it is important for a formers to build a relationship first, build a trust and look for the reason why someone could be a radical before doing the disengagement or deradicalization.

The formers have different views related to disengagement, especially when compared with the government or civil society approach. Based on the interview result there are several points that can be learned as a disengagement strategy by the formers. Some input is related to 1) Identification; 2) Categorization; 3) Person to Person Approach and Separation from the Group; 4) Gradual Disengagement Phase; 5) Simple Logic Delivery; 6) Moral Teaching; 7) Confidentiality Element; 8) Avoiding Debates and Seeking Momentum; 9) Psychological Approach; 10) Medium Selection; 11) Creating New Group Alternatives.

There are several strategies for the formers to make counter-narratives work well, and they are:

First, identification. Identification is an important part of knowing and understanding the identity, background characteristic and needs of disengagement beneficiaries. The formers need to understand the perspective of his opponents to minimize the mistakes in counternarratives. Sometimes the delivery error occurs because of over-generalization so it is necessary that identification, analysis and conclusion are needed before the construction process is resumed (Hassan in Horgan \& Braddock, 2012). The offenders have different backgrounds, characteristics and need so that coaching efforts cannot be performed in the same way. The offenders come from many cultural patterns, characteristic, social backgrounds, network, involvement motivation, political views, religious understanding, and their historical background are different from one another.

Second, categorization. Categorization is required to determine the understanding level of the offenders. In term of the understanding level (ideology) or its role in the network. Kurnia Widodo said:

"it is better for those who become a mediator to have classes or handling segments, for example: who is the most radical, who are the semi-different that should be forward".

In addition, there are differences in treatment among actors from ideologist and supporters. Person from the ideologist segment cannot be approached openly and require special treatment (Husaini, 2018; Hasan, 2018). The former who approaches the perpetrator of the ideologist category needs to have higher knowledge and charisma because they prefer to discuss religious and political issues. Hasan (2018) said that ideologist would think more to bring where this community was, while for supporters were more about combination of 
religious and humanitarian narratives depending on their motives joining the terrorist organization.

On the other hand, the offender who are in supporter classification have an approach pattern that is certainly different from ideologists. The duration of their network engagement and internalization of understanding was not long so the narrative presented needs to be simplified. Supporters have different motivations, some of them involved because they have an ideological understanding or some of them are involved because of the friend influence so they do not really understand the true essence of jihad. The narrative used for the offenders in this category is a combination of religious narratives and narratives of humanity. Regarding religious narratives, they need to be enlightened that what they do is not necessarily appropriate in the context of the verse they believed. Counter-narrative delivery strategies cannot be done through certain verses that are not necessarily understood by the perpetrators but are conveyed through a simple logic path (Patek, 2018). That simple logic flows can be supported by some examples of cases that the terror groups have tactic and strategies that are incompatible with religious teachings. On the other hand, related to humanitarian narratives, it is better to involve the perpetrators a discussion of some topic that motivates them to integrate them normally in the society such as related topic about family, economic or even education.

Third, Person to Person Approach and Separation from the Group. Personal communication is required to increase trust and place problem in context each individual has different characteristic and types of issues. Khairi (2018) stated some related example of disengagement in the prison. In the counter-narratives delivery within the prison should be separated from one of the strong network offenders. Khairi sees that:

"it is better to separate them. like ice cubes, if we want to melt them down then they need to be removed from the freezer. We should involve them on some activities. Although they will feel like a murtad (apostasy) person at first,but as the time passes by they will get used to it."

The extreme perpetrator have a tendency to be shoal and be exclusive. Their group still supply IS supporters by economic assistance through the foundation they manage to make them dependence. They will frighten to lose friends, to be mocked, alienated and physically attacked so it is important to get in touch with the perpetrators personally. Hanif (2018) give an example of his colleagues in prison called Niqob. He was joined IS group because he needs a brotherhood network to compete in the jail. He also needs economic support for himself because he does not have a family. It can be concluded that if counter-narrative does not offset with the supportive social environment will be hard for succeed.

Fourth, Gradual Disengagement. Sofyan Tsauri, a former who involved in military training in an Aceh and arms supply gave a realistic example that ideological moderation needs to be taken into account in the stage of thinking. There are four (4) stages of thought that he thinks can be used, namely: 1) Radical-Terrorist. A person who still have the motivation to commit violence; 2) Radical stage. The perpetrator has no motivation to commit violence but still have a radical understanding (disengage stage); 3) Moderate Stage, those who have accepted the difference and being tolerant (deradicalized stage); 4) The stage of Abangan, are those who already have identified as syncretized Islam identity (Tsauri, 2018). Tsauri stated that the efforts were done in order to make the perpetrator moderate only (Tsauri, 2018).

Tsauri said that he was using Osama bin Laden figure, an Al-Qaeda leader to moderate someone who were still on radical-terrorist stage. Osama is considered to have done a jihad evaluation step and is in the forefront of jihad so he worth to be heard. Tsauri recounts that his radicalism level was cannot be reduced directly, but gradually through the softer jihad narrative which was jihad narrative of Osama. Sofyan Tsauri inspired by Osama bin Laden 
after Osama wrote a letter of jihad evaluation called theLetter of Abbothabad. Inside the letter was written various evaluation of Jihad post-911 that had been damaged the Islam's face and reduced the sympathy of the Muslim community to the terror movement. Jihad needs to be more selective in certain areas and needs to calculate the benefit and the losses it generates. From the argument he stated, he tried to argue that the jihad movement was not rigid and could be made of various adjustments according to situation. The jihadist method of thinking needs to be adapted to the development of existing situations and conditions. Even though the use of Osama's narrative is not an ideal strategy, but the radical-mind reduction from previous radical-terrorist level can be reduced to 1 (one) lower level to a non-violent radical level. It is hoped that with the intervention of the state and the civil society element can consistently lower 1(one) level down, from the radical to the moderate stage.

Fifth, Simple Logic Use. Narrative submission is less effective using Pancasila narratives or using Islam Nusantara Narrative that is less likely to be favored by the perpetrator who is still posses radical mind. For example, Umar Patek conveyed to one of IS supporters in Prison in Porong that:

"when they entered the hall, they saw the big emblem of Garuda (symbol of Indonesia) as symbol of thoghut. Then I said that they should cut the Garuda symbol on 100.000 Rupiah money because that is the thoghut symbol". Well I did that. Because the money you value a lot should be cut because you hate the Garuda symbol. I told that to all the ISIS group that I met”.

The national normative ideology lecture can only be done when they were in the radical stage (non-violent). The narration needs to be packed by using narratives that use simple logic. The best narrative is more to teach ethics and morality.

Sixth, Moral Teaching. It is showed that a former likely to deliver education and moral narrative. The religious narrative is not fully effective if it delivers directly/ frontally (Hasan, 2018; Khairi, 2018). Most of the formers do not use offensive languages that can potentially make the perpetrators get hurt and make them more radical. Hasan who got enlightens from Umar Patek said that:

"wherever you are, you have to keep your morality, because Rasulullah sent to fix our morality. At war and peace, we need to keep our morality. It means if we have a power we could be more violent, for example in Mako Brimob riot, they (IS) kill people."(Hasan, 2018).

Khairi(2018) also got a lot of morality and courtesy of Abu Durjana both from oral and deed. Khairi was amazed by Abu Dujana character and nature. Khairi quoted from Abu Dujana:

"if someone mistreated us and cannot fight them back, we should be patient because Allah has his own considerations to us... I also saw a level of maturity, discipline, teamwork and life-lesson from him".

It is obvious that the former told them the negative impacts if they continue their violent habit and they encourage them to be patient.

Seventh,Confidentiality. The formers who became a counter-narrative narrator may not be openly claiming that he is a part of a country or society that will lead to resistance. There is a thought that the government is a decent antagonist figure labeled as thagut. It was experienced by one of the former Nasir Abbas on December 13, 2016, when he was couching on IS network group in Madiun Prison, and they are Abdullah Umamity (Ambon case), William Maksum (Poso case) and Andi Al-Kautsar (Poso case). Nasir Abbas reported got a light hit. The news was then exaggerated by IS network media. The former had to be cautious about character assasination. The confidentiality of their sponsor identity is something that must be taken care of as the former who is involved in disengagement (Hasan, 2018).They (IS) are 
very effective in managing and producing contents in social media (Hasan, 2018). Khairi added (2018), for those who still gruff do not use the state cover because they already have a negative thought about the state and they will treat the formers as a weapon to 'tame' them. The formers who have sponsor should be more cautious because the quantity of the credible formers was only a few so that confidentiality needed to be well kept.

Eight, Avoiding Confrontation and Seek for Momentum. If there is a debate on the particular topic, the formers should not put himself on debate. It could be a trap that would be a blunder for disengagement efforts. Such as a formers convict CIMB Niaga case (Initial AC, 2018), IS followers are tough person to accepting the truth, if they are approached by religious leaders they tend to be resistant and even distancing themselves. They do not want to argue with people who are more religious and they prefer a reference from internet which is written from someone they do not know personally (Initial AC, 2018).

Ali Fauzia former who had joined Jemaah Islamiyah said that someone who is still resisting the narrative should be answered with a diplomatic statement. To deal with those who are likely to be resistant, Fauzi recommend waiting for the certain momentum to approach. They will be more open when they need help. He exemplified the person who got a problem with the police because of traffic violations and that person called him by phone. Ali Fauzi pledge to the police to give relief and even provide economic support to the person who called him (Fauzi, 2018). Ali Fauzi's act should be appreciated because it could as it is able to dilute the relationship and make it easier to approach in the future. Hasan (2018) also pointed out that the moment when offenders needed help was when they were inside the prison. They really need attention and they will feel treated as human. Sometimes the terrorist prisoner is placed far from their family and rarely to see them so it could be a moment to approach them.

Ninth, Psychological Approach, counter-narrative does not need someone who has a big name. the most important thing is they should have a psychological closeness with them. sometimes the offenders do not want to meet senior or charismatic former. For instance, Umar Patek struggled into dialogue with one of the IS supporter group (initial AD) in Porong prison that related to $\mathrm{Abu}$ Roban terrorist network. Even though AD (initial) graduated from prestigious university, but Umar Patek considered that it was pretty difficult to discuss with him empirically. In another case, there are National Counter Terrorism Agency, a government body, initiated activities in 2015 by bringing religious figure to conduct counter-narrative effort, they are Syaikh Ali Hasan Al-Halabi from Jordan and Najih Ibrahim, Jamaah Islamiyah founder from Egypt. Although they are important figures in conducting disciplines on religious teachings, but according to one of the former criminal in Cipinang prison, many of the inmates did not want to meet them (Khairi, 2018). One of the former, Ibrahim (2018) said that:

"You do not need a great person to bring our brother back on the right path. The most important is our sincere and honest intention."

It can be concluded that the former approach to doing counter-narrative can be done if the former has gain trust, if the former does contradict the narrative directly without credibility it is feared that it would lead to misunderstanding of security threats to themselves.

Tenth, The Medium Selection. The messanger needs to consider the medium of information dissemination to disengagement goals. If he was radicalized through the influence of his friends, it would be best to use the network of friends in their in-group (initial AA, 2018; Hanif, 2018). Unlike someone who is being radicalized through the internet, it would be better to use social media to influence someone to abandon radicalism (initial AA, 2018). Many of the offenders who are radicalized through the IS from various backgrounds, so it is necessary counter-narrative designs are tailored to the intended audience. 
A former (AA) who has been involving in IS organization says that the IS group is different from the more commanded JI group. JI network group advantages such as pyramids as they are neatly arranged as having mantiqi (regional group) and wakalah (district group) system. The shortage of this pyramids networks is when 1 (one) person is caught all members of his network will be caught. While non-pyramid network such as IS are sporadic and their character is lacking clear regulations and not well trained. (Intial AA, 2018). Disengagement to IS followers needs a massive campaign on the Internet so that they likely to compare their religious knowledge they have.

Nurshadrina Khaira Dhania, a returnee who has been deceived by the IS on the internet said that she did not disengage by a former, but rather because of her own disappointment factor regarding the IS propaganda. She confessed as someone who is radicalized due to lack of critical thought and looking for a significance of her own life or doing something beyond her normal life. She believes in IS promises that she and her family will receive free amenities, get peace, free education, free healthcare and travel expenses will be replaced (Dhania, 2018 in Aditya, 2018).

For example, Aman Abdurrahman, an IS main reference in Indonesia once delivered in an interview with his views on the involvement of women and children in jihad in Surabaya (Khairi, 2018). At that moment Aman said that it is prohibited for women and children to join the jihad or worse attempt suicide bombings. But it turned out that Aman's opinion was not fully accepted by his followers and even Aman himself was opposed by his own supporters (Khairi, 2018). It is obvious that disengagement to IS supporter is more complex because the role of Aman in the organization are not fully successful in changing the mindset of their followers as they will seek for other references on the internet. Imron (2018) also said, radicalization process of IS supporters in Indonesia is not fully depend on Aman's fatwa, but inspired by the movement in Suriah (Imron, 2018).

Eleventh, Creating New Group Alternatives. The perpetrators who have already decrease their radicalism require new group alternatives as a place for them to reintegrate normally. Without creating a new group then the disengagement efforts will be useless and the offenders will get re-radicalized. Kurnia Widodo, a former of Cibiru bomber said the former in disengagement could not move on their own because they needed the community to provide them with good environmental support. They need to be given attention in the form of selfreliance or relief if he is still in prison in the form of remission. This community helps them to be independent so that they will detach easily from the radical group.

A new foundation initiated by the former has grown quite well in Indonesia. This organization was created by the on their own consciousness. These organizationsare among others: 1) Lingkar Perdamaian Foundation in Lamongan. The foundation was founded by Ali Fauzi a former of Jemaah Islamiyah group. The foundation is engaged to empower people exposed to radicalism; 2) Jalin Perdamaian Foundation in Aceh. This foundation was founded to accommodate former combatants in Aceh. The foundation seeks to create a productive place for former members who have been involved in jihad training in Jalin Janto Aceh and Former of (Free Aceh Movement; 3) The Afghan Alumni Communication Forum located in Jakarta which is a forum for Afghanistan combatants in Indonesia.

The eleven strategies outlined above are inputs that are the strategies from former in disengagement effort. To evaluate the success of the strategy, Tsauri (2018) paid attention to the simple observation strategy to the perpetrators: a) the willingness of the perpetrator to respond to the salam (greetings). If he wants to respond to the greeting then he does not consider people out of his groups as infidel; b) the willingness of the perpetrator to eat slaughtered animal. The perpetrators who are still radical assume the Indonesian Islamic 
identity is unclear that the perpetuation in slaughtering is also doubtful; c) the willingness of offenders to receive economic assistance. Economic aid from a person outside his group is considered to be the property of the infidels; d) The willingness of the offenders to pray in a public mosque. The mosque is considered a dhiror masque, a masque for spreading mischief and causing harm (Tsauri, 2018). With the four observation above can be seen indicators of infidelity and jihad the offenders still owned.

Even though the former are part of a credible presenter, however, the disengagement effort through the former is not a single strategy because the approach through the former is just one of many disengagement strategies if there is a constraint in its implementation, disengagement effort through the role of victim and families can be alternative, even the internet media can play a role in disengagement effort (Aditya, 2018). Disengagement approach through the formers still face some challenge because not the entire former has the ability to get in touch with ideology level with the perpetrators. Therefore, it is necessary to do coaching periodically so that the former involved will make better contribution in disengagement effort.

\section{CONCLUSION}

The former proved as credible counter-narrative messenger in order to disengage the offenders who are still radical in Indonesia. The former has launched various counter-narrative delivery strategies so that the management is more humanistic. The delivery pattern is not done by attacking the ideology in direct way, but by using softer narratives so that they can build a long-term relationship. There is an assumption that the disengagement full of theology narrative. This assumption is true, but if it is not matched with humanitarian-narrative, the disengagement effort will meet the obstacle. The ideas conveyed by the former using a simple logic without hurting their feeling are a matter of long-term relationships. Formers have experiences that ideology is something that difficult to changed so that it require consistency and environmental adjustment so that the message can be conveyed properly. Ideology of the offenders thought are strongly formed because of being in a harsh social environment so the offenders need to be separated first from their gruff environment before delivering the counter-narratives.

\section{ACKNOWLEDGEMENT}

This research based on grant scheme of PITTA (Publikasi International Terindeks untuk Tugas Akhir) or also known as Indexed International Publications for Final Projects toward Universitas Indonesia students. Thank you to Dr. Muhammad Luthfi as my advisor

\section{REFERENCE}

[1]. Aditya, N.F. (2018). Perempuan dan Terorisme: Deradikalisasi Online Melalui Metode Narasi Alternatif. Analisis CSIS, 47 (1), 115-132

[2]. Al Raffie, D. (2012). "Whose Hearts and Minds? Narratives and Counter Narrative of Salafi Jihadism", Journal of Terrorism Research, 3 (2): 13-31.

[3]. Alonso, R. (2016). What Role Have Former ETA Terrorists Played in Counterterrorism and Counterradicalization Initiatives in Spain? Studies in Conflict and Terrorisme. https://doi.org/10.1080/1057610X.2016.1154365 
[4]. Argomaniz, J. \& Lynch, O (2017). Introduction to the Special Issue: The Complexity of Terrorism-Victims, Perpetrators and Radicalization, Studies in Conflict \& Terrorism, DOI: 10.1080/1057610X.2017.1311101

[5]. Benford, D \& Snow, D. "Framing Processes and Social Movement: An Overview and Assessment, "Annual Review of Sociology 26 (1) (2000) dalam Clubb, G. (2016): The Role of Former Combatants in Preventing Youth Involvement in Terrorism in Northern Ireland: A Framework for Assessing Former Islamic StateCombatants. Studies in Conflict \& Terrorism. http://dx.doi.org/10.1080/1057610X.2016.1144917

[6]. Bjorgo, T. Process of Disengagement from Violent Groups of the Extremist Right. Bjorgo, T., \& Horgan, J. (Eds.). (2008). Leaving Terrorism Behind: Individual And Collective Disengagement. Routledge.

[7]. Briggs, R \& Feve, S. Report on Review of Programs to Counter Narratives of Violent Extremism: What Works and What Are the Implications for Government. http://www.strategicdialogue.org/ISD_Kanishka_Report.pdf, Institute for Strategic Dialogues, 2013.

[8]. Christensen, T.W. (2015). How Extremist Experiences Become Valuable Knowledge in EXIT Programmes. Journal of Deradicalization. http://journals.sfu.ca/jd/index.php/jd/article/view/18/18

[9]. Clubb, G. (2016): The Role of Former Combatants in Preventing Youth Involvement in Terrorism in Northern Ireland: A Framework for Assessing Former Islamic StateCombatants. Studies in Conflict \& Terrorism. http://dx.doi.org/10.1080/1057610X.2016.1144917

[10]. Glazzard, A. (2017). Losing the Plot: Narrative, Counter Narrative and Violent Extremism. ICCT Research Paper. DOI: 10.19165/2017.1.08

[11]. Hassan, M.H.B., Key Consideration in Counterideological Work Against Terrorist Ideology dalam Horgan, J., \& Braddock, K. (Eds.). (2012). Terrorism studies: A Reader. Routledge.

[12]. Hemmingsen, A.S and Castro Møller, K (2017) The Trouble with counter narratives. Danish Institute for International Studies, Report 2017: 1.

[13]. Horgan, J. (2008). Deradicalization or Disengagement?" A Journal of the Terrorism Research Initiatives. Vol.2 (4).

[14]. Horgan, J. \& Braddock, K. (2010). Rehabilitating the Terrorist? Challenges in Assessing The Effectiveness of Deradicalization Programs. Terrorism and Political Violance, Vol. 22 (2).

[15]. Horgan, J. G., \& Horgan, J. (2004). The Psychology of Terrorism. Routledge.

[16]. http://pure.diis.dk/ws/files/784884/DIIS_RP_2017_1.pdf, localised June 10, 2017

[17]. Hwang, J.C. (2017). "The Disengagement of Indonesian Jihadists: Understanding the Pathways" Terrorism and Political Violence Vol. 29 (2).

[18]. Idris, I. \& Taufiqurrahman, M. Current State of Indonesia's Deradicalisation and Rehabilitation Programme. Gunaratna, R., \& Ali, M. B. (Eds.). (2015). Terrorist rehabilitation: A new frontier in counter-terrorism. Imperial College Press.

[19]. Jacobson, M. (2009). Terrorist Drop-Outs: One Way Of Promoting A CounterNarrative. Perspectives on Terrorism, 3(2), 12-17.

[20]. Jacobson, M. (2010). Learning Counter-Narrative Lessons from Cases of Terrorist Dropouts. Countering Violent Extremist Narratives, 72-83.

[21]. Rabasa, A., Pettyjohn, S. L., Ghez, J. J., \& Boucek, C. (2010). Deradicalizing Islamist Extremists. RAND Corp Arlington VA National Security Research Div. 
[22]. Ruston, S.W. (2009). "Understanding What Narrative is and Does." Arizona State University Center for Strategic Communication, September 3. http://csc.asu.edu/2009/09/03/understand-what-narrative-is-and-does/

[23]. Sageman M. (2008). Leaderless Jihad: Terror Network in The Twenty First Century. Philadelphia, United States of America: University of Pennsylvania Press.

[24]. Schmid, A.P. "Al-Qaeda's "Single Narrative" and Attempts to Develope Counternarrative: The State of Knowledge." International Center for Counter Terrorism, January 2014. https://www.icct.nl/download/file/Schmid-Al-Qaeda'sSingle-Narrative-and-Attempts-to-Develop-Counter-Narratives-January-2014.pdf

[25]. Schmid, A.P. Democratic Leadership. Oktober 13, 2016. http://stoppingviolentextremism.org/the-search-for-an-alternative-narrative/

[26]. Sieckelinck, S. de Winter, Micha (eds.) Formers \& Families: Transitional Journeys In And Out Of Extremisms In The United Kingdom, Denmark And The Netherland. National Coordination for Security and Counterterrorism: Ministry of Security and Justice.

[27]. AA (2018). Interview to the Former. Agustus 31st, 2018.

[28]. AB (2017). Interview to the Former, Februari 1st, 2017.

[29]. AC (2018). Interview to the Former, July 11th, 2018.

[30]. Fauzi, A. (2018). Interview to the Former, July 10th, 2018.

[31]. Husaini, I. (2018). Interview to the Former, August 23rd, 2018.

[32]. Ibrahim, E. (2018). Interview to the Former, April 12th, 2018.

[33]. Khairi, M. (2018). Interview to the Former, May 31st, 2018

[34]. Hasan. (2018). Interview to the Former, June 20th, 2018

[35]. Dhania, N.K., Interview to the Returnee, April 16th, 2018

[36]. Imron, A., Interview to the Terrorist Inmates, September 25th, 2018

[37]. Hanif. (2018). Former Interview, June 24th, 2018.

[38]. Tsauri, S. (2018). Former Interview, September 9th, 2018.

[39]. Widodo, K. (2018). Former Interview, April 3rd, 2018.

[40]. Patek, U (2018). Interview to the Terrorist Inmates, June 12th, 2018. 